\title{
Impact of elevated ozone concentration on growth, physiology, and yield of wheat (Triticum aestivum L.): a meta-analysis
}

\author{
ZHAOZHONG FENG*†, KAZUHIKO KOBAYASHI* and ELIZABETH A. AINSWORTH \\ *Department of Global Agricultural Sciences, Graduate School of Agricultural and Life Sciences, The University of Tokyo, Tokyo \\ 113-8657, Japan, †State Key Laboratory of Urban and Regional Ecology, Research Center for Eco-Environmental Sciences, Chinese \\ Academy of Sciences, Beijing 100085, China, †USDA ARS Photosynthesis Research Unit and Department of Plant Biology, \\ University of Illinois, Urbana-Champaign, 147 ERML, 1201 W. Gregory Drive, Urbana, IL 61801, USA
}

\begin{abstract}
We quantitatively evaluated the effects of elevated concentration of ozone $\left(\mathrm{O}_{3}\right)$ on growth, leaf chemistry, gas exchange, grain yield, and grain quality relative to carbonfiltered air (CF) by means of meta-analysis of published data. Our database consisted of 53 peer-reviewed studies published between 1980 and 2007, taking into account wheat type, $\mathrm{O}_{3}$ fumigation method, rooting environment, $\mathrm{O}_{3}$ concentration $\left(\left[\mathrm{O}_{3}\right]\right)$, developmental stage, and additional treatments such as drought and elevated carbon dioxide concentration $\left(\left[\mathrm{CO}_{2}\right]\right)$. The results suggested that elevated $\left[\mathrm{O}_{3}\right]$ decreased wheat grain yield by $29 \%$ (CI: $24-34 \%$ ) and aboveground biomass by $18 \%$ (CI: 13-24\%), where CI is the $95 \%$ confidence interval. Even in studies where the $\left[\mathrm{O}_{3}\right]$ range was between 31 and $59 \mathrm{ppb}$ (average $43 \mathrm{ppb}$ ), there was a significant decrease in the grain yield (18\%) and biomass $(16 \%)$ relative to $C F$. Despite the increase in the grain protein content $(6.8 \%)$, elevated $\left[\mathrm{O}_{3}\right]$ significantly decreased the grain protein yield $(-18 \%)$. Relative to $\mathrm{CF}$, elevated $\left[\mathrm{O}_{3}\right]$ significantly decreased photosynthetic rates $(-20 \%)$, Rubisco activity $(-19 \%)$, stomatal conductance $(-22 \%)$, and chlorophyll content $(-40 \%)$. For the whole plant, rising $\left[\mathrm{O}_{3}\right]$ induced a larger decrease in belowground $(-27 \%)$ biomass than in aboveground $(-18 \%)$ biomass. There was no significant response difference between spring wheat and winter wheat. Wheat grown in the field showed larger decreases in leaf photosynthesis parameters than wheat grown in $<5 \mathrm{~L}$ pots. Open-top chamber fumigation induced a larger reduction than indoor growth chambers, when plants were exposed to elevated $\left[\mathrm{O}_{3}\right]$. The detrimental effect was progressively greater as the average daily $\left[\mathrm{O}_{3}\right]$ increased, with very few exceptions. The impact of $\mathrm{O}_{3}$ increased with developmental stages, with the largest detrimental impact during grain filling. Both drought and elevated $\left[\mathrm{CO}_{2}\right]$ significantly ameliorated the detrimental effects of elevated $\left[\mathrm{O}_{3}\right]$, which could be explained by a significant decrease in $\mathrm{O}_{3}$ uptake resulting from decreased stomatal conductance.
\end{abstract}

Keywords: air pollution, atmospheric change, biomass, elevated $\left[\mathrm{CO}_{2}\right]$, global change, grain quality, ozone, photosynthesis, stomata, yield component

Received 1 February 2008 and accepted 10 March 2008

Introduction

Ozone $\left(\mathrm{O}_{3}\right)$ is currently considered to be the most important air pollutant affecting plant productivity in most parts of the world (Fowler et al., 1999a; Krupa et al., 2001; Feng et al., 2003; Ashmore, 2005; Wang et al.,

Correspondence: Kazuhiko Kobayashi, fax + 8135841 5186,

e-mail: aclasman@mail.ecc.u-tokyo.ac.jp
2005; EPA US, 2006; Karnosky et al., 2007; Mittal et al., 2007; Wang et al., 2007a), not only because of its phytotoxicity (Krupa et al., 2001) but also because its concentration has risen at a rate of $0.5-2 \%$ per year during the past three decades (Vingarzan, 2004). Nearly one-quarter of the earth's surface is currently at risk from elevated $\left[\mathrm{O}_{3}\right]$ in excess of $60 \mathrm{ppb}$ during mid-summer, with even greater concentrations occurring locally 
(Fowler et al., 1999b). Models predicted that tropospheric $\left[\mathrm{O}_{3}\right]$ could rise $20-25 \%$ between 2015 and 2050 , and further increase by $40-60 \%$ by 2100 if current emission trends continue (Meehl et al., 2007).

There is abundant evidence that current ambient $\left[\mathrm{O}_{3}\right]$ in many areas of the world is high enough to induce significant yield losses in crops such as wheat (Wahid et al., 1995; Wang et al., 2007b), potato (Clarke et al., 1990), soybean (Nali et al., 2002; Morgan et al., 2003), and rice (Ainsworth, 2008). Ozone, a strong oxidant, primarily enters plants through the stomata where it can dissolve in the apoplastic liquid. Ozone can directly react with the plasmalemma through ozonolysis or it can be converted into reactive oxygen species (ROS) and hydrogen peroxide $\left(\mathrm{H}_{2} \mathrm{O}_{2}\right)$, which alter cellular components and can lead to cell death, accelerated senescence, and the up- or down-regulation of genes (Long \& Naidu, 2002; Fiscus et al., 2005). In the chloroplast, these reactions could directly or indirectly impair the light and dark reactions of photosynthesis (Fiscus et al., 2005). Physiological studies indicate that $\mathrm{O}_{3}$ damaged the photosynthetic machinery leading to reduced fixation and a progressive loss of ribulose-1,5bisphosphate carboxylase/oxygenase (Rubisco) activity despite no visible injury (Ojanpera et al., 1998; Fiscus et al., 2005). The deleterious effects of $\mathrm{O}_{3}$ on the grain yield have often been attributed to premature leaf senescence, decreases in light interception and photosynthesis, consequent reductions in assimilate availability, and alterations in assimilate partitioning (Heagle, 1989; Kobayashi \& Okada, 1995; Kobayashi et al., 1995; Nouchi et al., 1995; Mulholland et al., 1998; Black et al., 2000; Feng et al., 2007).

At the whole-plant level, chronic $\mathrm{O}_{3}$ exposure can lead to visible leaf injury and reductions in biomass and yield (Heagle, 1989; Kobayashi et al., 1995; Benton et al., 2000; Feng et al., 2003; Fuhrer \& Booker, 2003; Morgan et al., 2003; Ashmore, 2005; Wang et al., 2007b), although the observed responses vary depending on the species and exposure conditions (Heagle, 1989; Fuhrer \& Booker, 2003; Fiscus et al., 2005; Mills et al., 2007). A wide variation in the magnitude and direction of $\mathrm{O}_{3}$ responses has been reported within a single species (Morgan et al., 2003). For example, visible leaf damage varied from no discernable damage to $>80 \%$ loss of leaf green area for spring wheat (Finnan et al., 1998; Booker, 2004). Rape seed yield ranged from a decrease of $>35 \%$ (Adaros et al., 1991) to an increase of $>20 \%$ (Kollner \& Krause, 2003). Variability results from differences in genetic background and developmental stage, as well as $\mathrm{O}_{3}$ concentration patterns and exposure dose. When crops were exposed to $\mathrm{O}_{3}$ from the vegetative stage until maturity, sensitivity of seed crops to $\mathrm{O}_{3}$ was greatest during the period between flowering and seed maturity (Lee et al., 1988), which was supported by experimental studies of beans (Phaseolus vulgaris; Younglove et al., 1994) and spring wheat (Ewert \& Pleijel, 1999). Ewert \& Pleijel (1999) summarized spring wheat cv. Minaret grown in open-top chambers (OTCs) at different sites throughout Europe for up to 3 years at each site, and found that $\mathrm{O}_{3}$ exposure reduced the leaf area index (LAI) by ca. $9 \%$ at anthesis, but had hardly any effect during the stem elongation stage.

Rising $\left[\mathrm{O}_{3}\right]$ is often studied along with other environmental factors such as elevated $\left[\mathrm{CO}_{2}\right]$ and drought. Factors that influence the stomatal conductance can alter the flux of $\mathrm{O}_{3}$ into mesophyll. Numerous studies demonstrated that water stress or elevated $\left[\mathrm{CO}_{2}\right]$ significantly decreased the relative impact of $\mathrm{O}_{3}$ in many crops and natural vegetation (Mulholland et al., 1998; Fuhrer \& Booker, 2003; Khan \& Soja, 2003; Valkama et al., 2007; Wittig et al., 2007).

Wheat is an important crop worldwide and is grown on about 200 million hectares in a range of environments, with an annual production of more than 619 million metric tons (FAO, 2007). Global wheat production must continue to increase $2 \%$ annually until 2020 to meet future demands imposed by population and prosperity growth (Singh et al., 2007). Attaining this goal is made more difficult under the reduced water availability, global warming, and atmospheric pollution predicted for the future. Wheat is known to be among the most $\left[\mathrm{O}_{3}\right]$-sensitive crops (Mills et al., 2007) and is frequently used as a model annual C3 crop to assess future food security. A large number of studies have investigated the response of its growth, physiology, and yield to elevated $\left[\mathrm{O}_{3}\right]$ and other environmental factors that may impact the $\mathrm{O}_{3}$ response. In the work presented here, we have used metaanalyses to determine the mean responses of wheat growth and production to the current and future elevation of $\left[\mathrm{O}_{3}\right]$.

The objectives of this paper are (1) to summarize and synthesize the results of the numerous studies on physiology, growth, grain yield and its components, and grain quality of wheat in response to elevated $\left[\mathrm{O}_{3}\right]$, and (2) to reveal the sources of variation in the wheat responses to elevated $\left[\mathrm{O}_{3}\right]$. We thereby addressed the following questions: (1) To what extent is the grain yield of wheat reduced by elevated $\left[\mathrm{O}_{3}\right]$, and which parameters are associated with the yield reduction? (2) Are wheat responses to $\mathrm{O}_{3}$ dependent on growth stages, wheat type, fumigation method, and rooting environment? (3) Does elevated $\left[\mathrm{CO}_{2}\right]$ or drought modify the effects of elevated $\left[\mathrm{O}_{3}\right]$ on wheat growth? (4) To what extent do current ambient and future $\left[\mathrm{O}_{3}\right]$ affect wheat yield? 


\section{Materials and methods}

\section{Database}

Using the Web of Science (Thompson-ISI, Philadelphia, PA, USA) and AGRICOLA databases (National Agricultural Library, Beltsville, MD, USA), a survey of all peerreviewed literature published between 1980 and 2007 was made on wheat photosynthesis, growth, yield and its components, and grain quality responses to elevated $\left[\mathrm{O}_{3}\right]$. Articles and experiments were excluded if (1) only aggregate means were reported across treatments or cultivars, (2) ozone fumigation was less than 10 days, (3) the experimental control was ambient air, (4) elevated $\left[\mathrm{O}_{3}\right]$ was less than $30 \mathrm{ppb}$ during exposure, (5) the data were previously or more completely reported in another article. After excluding articles based on these criteria, 53 articles were used for the meta-analysis (Appendix A). The articles were examined for any of the plant growth parameters listed in Table 1. The mean value, the standard deviations, and the replication in carbon-filtered air (CF) and elevated $\left[\mathrm{O}_{3}\right]$ were recorded in a database together with the categorical information. Data from the figures were digitized using data extraction software (GRAFUlA 3 v.2.10, Wesik SoftHaus, St Petersburg, Russia). If gas exchange measurements were made over the diurnal course, only values for light-saturating conditions were recorded in the database. Meta-analytic methods require that individual observations be statistically independent. Parameter values were considered independent if they were made on different cultivars, $\mathrm{O}_{3}$ concentrations, additional treatments, or if the measurements were made on different dates in the same experiment, following previous meta-analyses (Curtis \& Wang, 1998; Ainsworth et al., 2002; Morgan et al., 2003; Wittig et al., 2007).

\section{Sources of variation}

To explain the variation in the response of wheat to elevated $\left[\mathrm{O}_{3}\right]$, seven categories were included as follows: (1) wheat type (spring wheat vs. winter wheat); (2) fumigation method (OTC, growth chamber, and greenhouse); (3) developmental stage (seedling, booting-anthesis, grain filling, and maturity); (4) rooting environment (field, <5L pot, and $\geq 5 \mathrm{~L}$ pot); (5) duration of leaf fumigation $(3-10,11-20,21-30$, and $\geq 31$ days); (6) mean $\left[\mathrm{O}_{3}\right]$ (30-59, 60-89, 90-119, and $\geq 120 \mathrm{ppb}$ ); and (7) additional treatments (no additional treatments, elevated $\left[\mathrm{CO}_{2}\right]$, or drought). Note that the results of 3-10-day leaf exposure were extracted from studies that had a total fumigation period of more than 10 days. The mean $\left[\mathrm{O}_{3}\right]$ in the control and in the
Table 1 List and definitions of response variables reported on in this meta-analysis

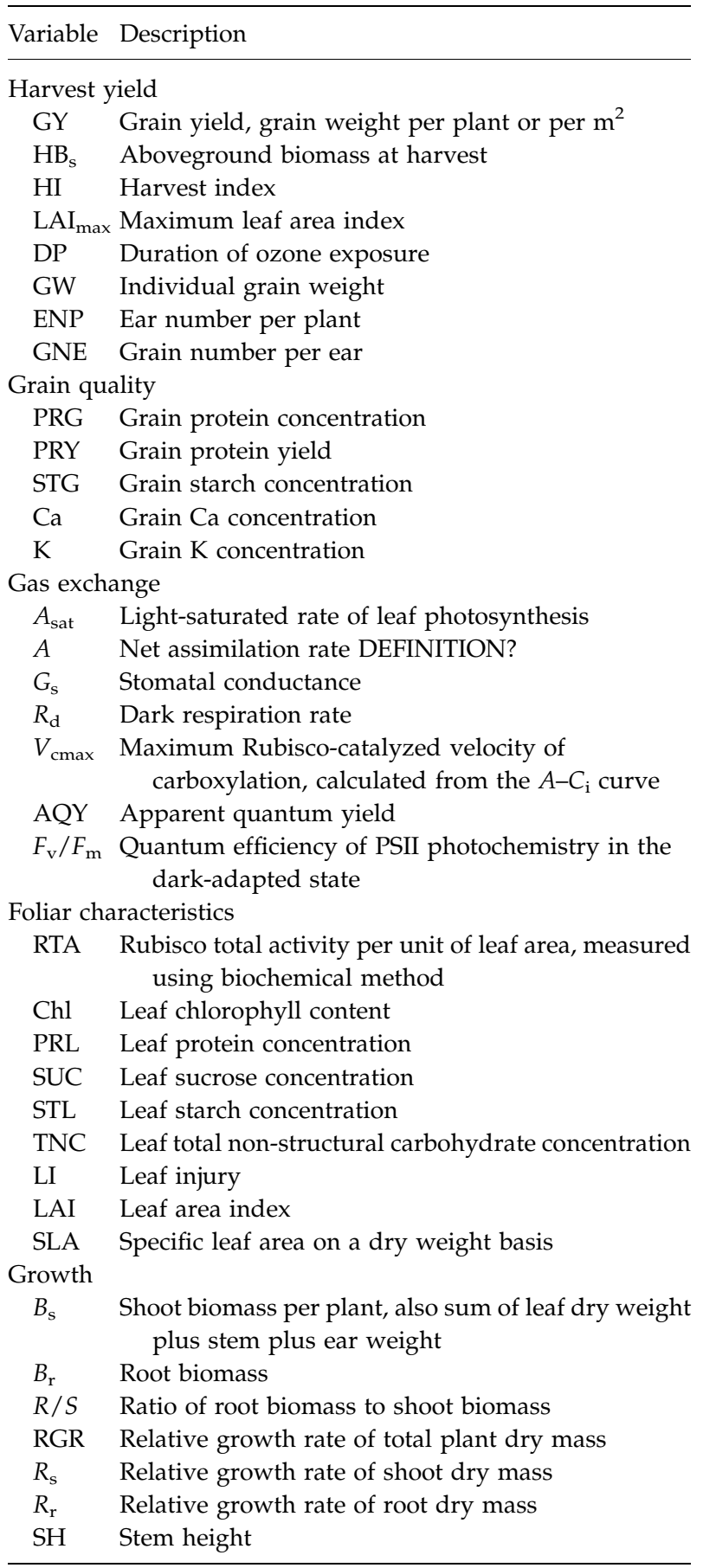

treatment was defined for the period of $\mathrm{O}_{3}$ fumigation, which ranged from 7 to $12 \mathrm{~h} \mathrm{day}^{-1}$.

\section{Meta-analyses}

Following the techniques of Curtis \& Wang (1998), the meta-analysis was conducted using a meta-analytical 
software package (METAWIN 2.1.3.4, Sinauer Associates, Inc., Sunderland, MA, USA) (Rosenberg et al., 2000). To estimate the treatment effect, the natural $\log$ of the response ratio $\left(r=\right.$ variable in elevated $\left[\mathrm{O}_{3}\right] /$ variable in $\mathrm{CF}$ air) was used as the metric for analysis (Hedges et al., 1999; Rosenberg et al., 2000) and reported as the percentage changes from control as $(r-1) \times 100 \%$ (Curtis \& Wang, 1998; Ainsworth et al., 2002; Morgan et al., 2003; Ainsworth \& Long, 2005; Wittig et al., 2007). Negative percentage changes indicate a decrease in the variable in response to elevated $\left[\mathrm{O}_{3}\right]$ treatment, while positive values indicate an increase.

A limited number of manuscripts reported data that would allow computation of sample variance (standard deviations or standard errors with replicate size). Therefore, most response variables except leaf starch and sucrose were analyzed using an un-weighted approach, in which the variance of the effect size was calculated using resampling techniques after 9999 iterations (Adams et al., 1997; Gurevitch \& Hedges, 1999; Rosenberg et al., 2000; Ainsworth et al., 2002; Morgan et al., 2003). Confidence limits around the effect size were calculated using a bootstrap method (Rosenberg et al., 2000). Estimates of the effect size were assumed to be significant if the $95 \%$ confidence intervals (CI) did not overlap zero (Curtis \& Wang, 1998). The difference between categorical variables was considered significant if the 95\% CI did not overlap (Curtis \& Wang, 1998; Ainsworth et al., 2002; Morgan et al., 2003). Levels of each category were included in this analysis if there were at least 10 observations, or three independent articles. Because of limited observations in different leaf fumigation periods and in combined effects of elevated $\left[\mathrm{O}_{3}\right]$ and drought, two independent articles with less than 10 measurements were also used in these two categorical analyses.

\section{Results}

\section{Overall effects of elevated $\left[\mathrm{O}_{3}\right]$}

Across all studies, elevated $\left[\mathrm{O}_{3}\right]$ with a range of 31$200 \mathrm{ppb}$ decreased wheat grain yield by $29 \%$, with a $95 \%$ CI of $24-34 \%$ (Fig. 1). The large yield loss was caused by a combination of decreases in individual grain weight $(-18 \%)$, ear number per plant $(-6 \%)$, and grain number per ear $(-11 \%)$. Harvest index was decreased by ca. $9 \%$, although the decrease in aboveground dry weight at maturity $(-18 \%)$ contributed more to the $29 \%$ yield loss. Elevated $\left[\mathrm{O}_{3}\right]$ increased the grain nutritional content, such as protein $(+7 \%)$, $\mathrm{Ca}(+11 \%)$, and $\mathrm{K}(+9 \%)$, whereas it reduced the starch content by $8 \%$. The increase in the grain protein content was not large enough to compensate for the

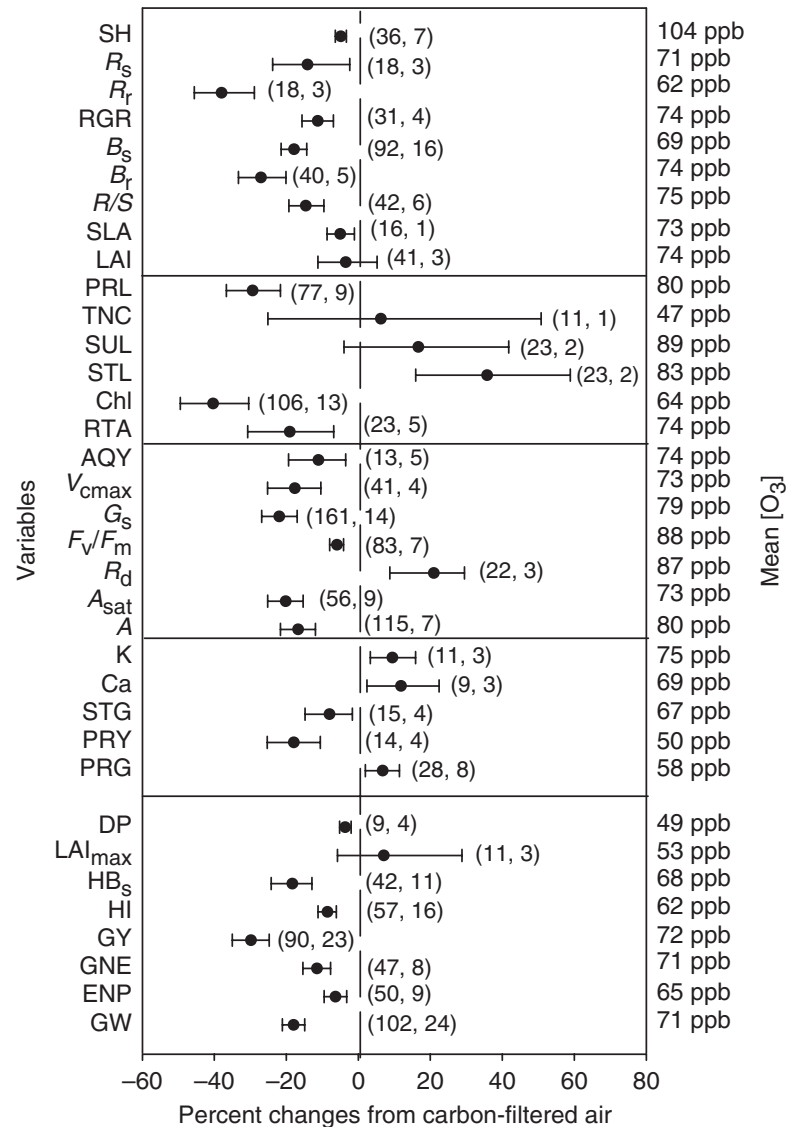

Fig. 1 Effect of elevated $\left[\mathrm{O}_{3}\right]$ on wheat biomass allocation, leaf characteristics, gas exchange, grain quality, and yield components. Symbols represent the mean percent change at elevated $\left[\mathrm{O}_{3}\right]$ relative to carbon-filtered air, and the bars show the $95 \%$ confidence intervals (CIs). Number of measurements and studies are shown in parentheses, respectively, and average $\left[\mathrm{O}_{3}\right]$ is given on the $y$-axis. Abbreviations for the parameters are described in Table 1.

yield loss, and the grain protein yield was reduced significantly by $18 \%$. Elevated $\left[\mathrm{O}_{3}\right]$ accelerated the senescence relative to $\mathrm{CF}$ treatment, as shown by a shorter $(-4 \%)$ duration from sowing to maturity.

LAI and SLA (specific leaf area) were not significantly affected by elevated $\left[\mathrm{O}_{3}\right]$, whereas a $20 \%$ decrease in leaf photosynthetic rate and a $21 \%$ increase in leaf dark respiration rate were induced. Lower photosynthetic rates may have resulted from combined effects of decreases in Rubisco activity $(-19 \%), V_{\text {cmax }}(-18 \%)$ and stomatal conductance $(-22 \%)$, and a large decrease in chlorophyll content $(-40 \%)$ and light use efficiency $(-11 \%)$. Along with the decrease in leaf $F_{\mathrm{v}} / F_{\mathrm{m}}(-6 \%)$, leaf photosynthetic light and dark reactions capacity was decreased, which should have resulted in less available carbon for growth and grain formation when exposed to elevated $\left[\mathrm{O}_{3}\right]$. Leaf chemistry responses 
revealed that protein content was decreased by $29 \%$ while starch content was increased by $40 \%$ at elevated $\left[\mathrm{O}_{3}\right]$. There was a trend toward increased leaf TNC (total nonstructural carbohydrate concentration) and sucrose at elevated $\left[\mathrm{O}_{3}\right]$, although the effect was not significant.

For the whole plant, elevated $\left[\mathrm{O}_{3}\right]$ induced a larger decrease in belowground $(-27 \%)$ than in above-ground $(-18 \%)$ biomass, regardless of the total biomass accumulation or growth rate. Correspondingly, the root-toshoot ratio was decreased by $15 \%$ under elevated $\left[\mathrm{O}_{3}\right]$ relative to the $\mathrm{CF}$ treatment. Moreover, the $\mathrm{O}_{3}$ exposure caused lower RGR $(-11 \%)$ and height $(-5 \%)$.

Difference between wheat types in the effects of elevated $\left[\mathrm{O}_{3}\right]$

Significant differences were found only in stomatal conductance and leaf chlorophyll concentration between spring wheat and winter wheat (Fig. 2). The chlorophyll result is confounded by the fact that only one study was conducted in the seedling stage for winter wheat. Although $\left[\mathrm{O}_{3}\right]$ during winter wheat

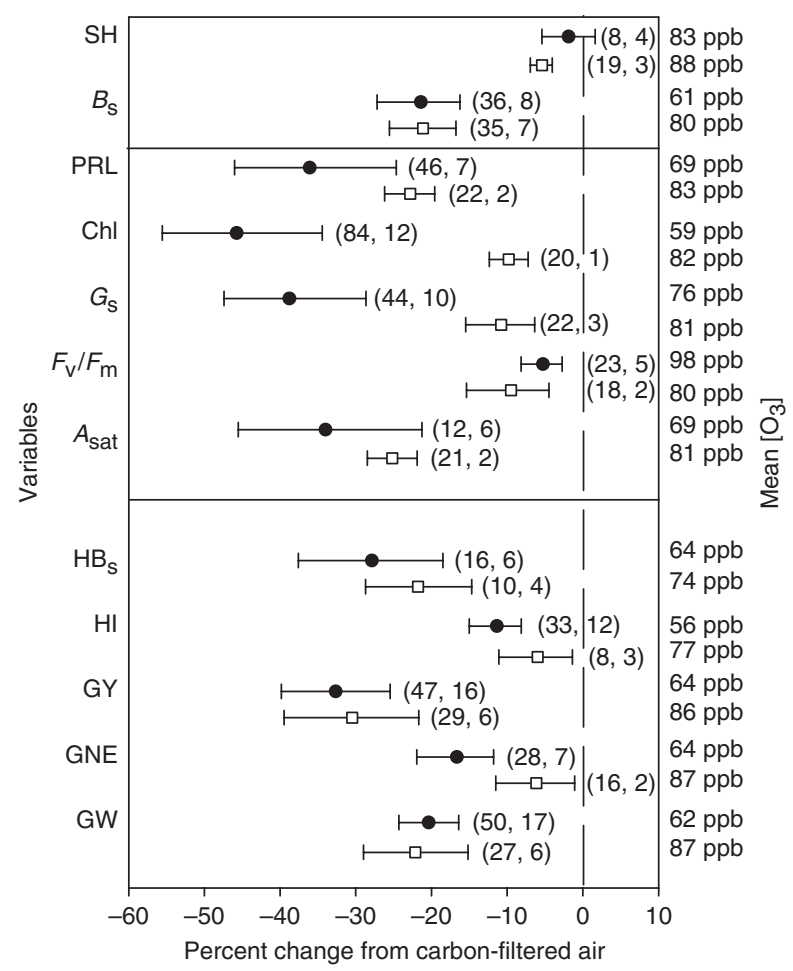

Fig. 2 Effects of elevated $\left[\mathrm{O}_{3}\right]$ on spring wheat $(\bullet)$ and winter wheat $(\square)$, excluding studies that involved additional treatments. Number of measurements and studies are shown in parentheses, respectively, and average $\left[\mathrm{O}_{3}\right]$ is given on the $y$ axis. Abbreviations for the parameters are described in Table 1.

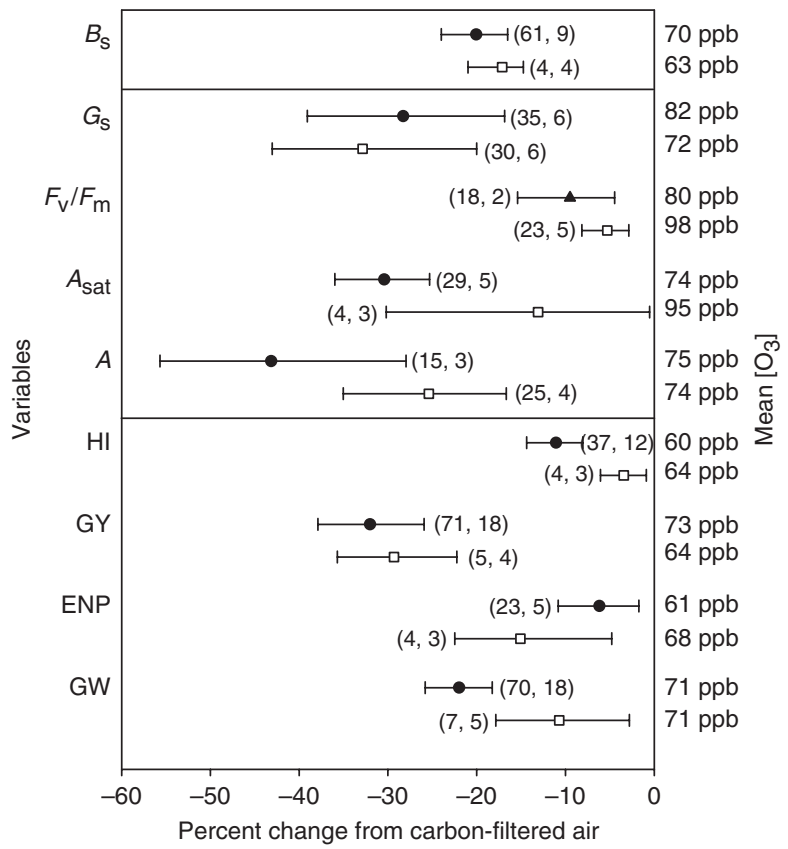

Fig. 3 Effects of elevated $\left[\mathrm{O}_{3}\right]$ on wheat with different ozone fumigation methods, excluding studies that involved additional treatments. Ozone fumigation method using open-top chamber $(\bullet)$, using indoor growth chamber $(\square)$, and greenhouse $(\boldsymbol{\Delta})$. Number of measurements and studies are shown in parentheses, respectively, and average $\left[\mathrm{O}_{3}\right]$ is given on the $y$-axis. Abbreviations for the parameters are described in Table 1.

fumigation was higher than that for spring wheat, most variables showed little difference between winter wheat and spring wheat in the responses to elevated $\left[\mathrm{O}_{3}\right]$.

\section{Effect of ozone fumigation methods}

The experiments with OTCs were associated with larger decreases for most variables compared with those with growth chambers or greenhouses with significant differences being found in individual grain weight, harvest index, and leaf protein concentration (Fig. 3).

\section{Effect of rooting environment}

Relative to plants grown in $<5 \mathrm{~L}$ pots, those grown in the field showed greater decrease due to elevated $\left[\mathrm{O}_{3}\right]$ in leaf photosynthesis parameters: about twofold in $A_{\text {sat }}$ 4.5-fold in leaf chlorophyll, and 2.3-fold in leaf protein concentrations (Fig. 4). However, there was a larger decrease in aboveground biomass for wheat grown in large pot size $(5-15 \mathrm{~L})$ than those grown in the field. 


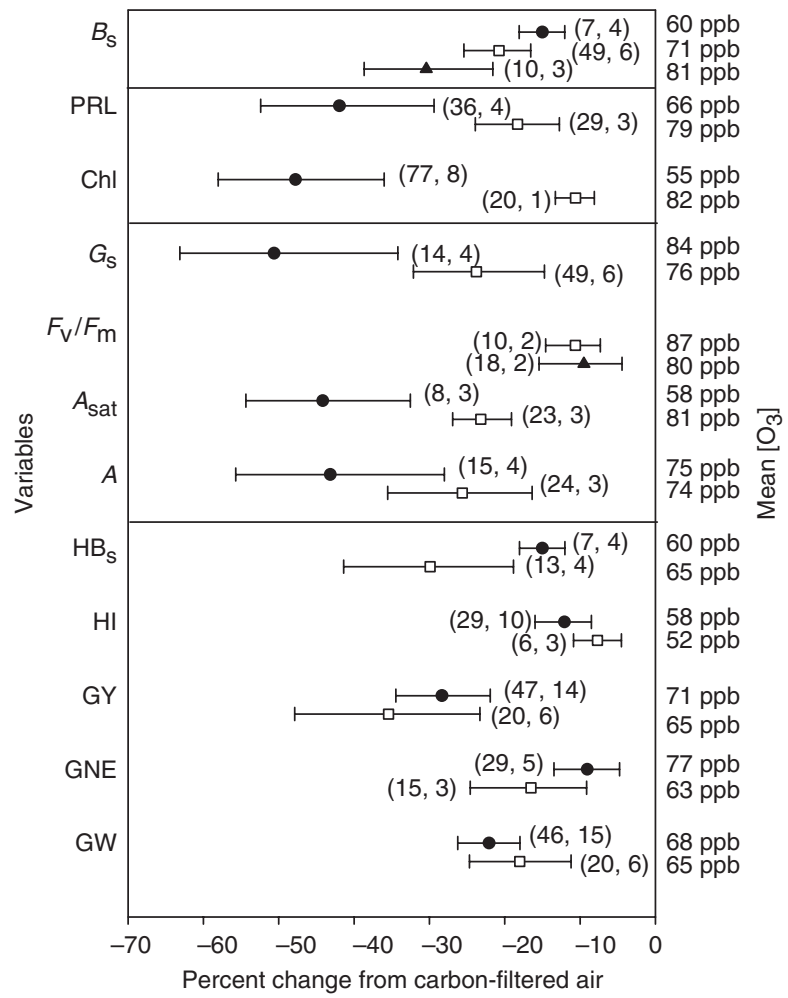

Fig. 4 Effects of elevated $\left[\mathrm{O}_{3}\right]$ on wheat grown in field $(\bullet)$, in $<5 \mathrm{~L}$ pots $(\square)$, and in $\geq 5 \mathrm{~L}$ pots $(\boldsymbol{\Lambda})$, excluding studies that involved additional treatments. Number of measurements and studies are shown in parentheses, respectively, and average $\left[\mathrm{O}_{3}\right]$ is given on the $y$-axis. Abbreviations for the parameters are described in Table 1.

\section{Effect of ozone concentration}

The detrimental effect of $\mathrm{O}_{3}$ was progressively greater as the average daily $\left[\mathrm{O}_{3}\right]$ increased, with very few exceptions (Fig. 5). In some variables (e.g. shoot biomass, individual grain weight, and grain yield), the decrease induced by elevated $\left[\mathrm{O}_{3}\right]$ was significantly greater in high $\left[\mathrm{O}_{3}\right]$ than that in lower $\left[\mathrm{O}_{3}\right]$ ranges. It is also noteworthy that many plant parameters showed significant response to elevated $\left[\mathrm{O}_{3}\right]$ relative to $\mathrm{CF}$ at the lowest $\left[\mathrm{O}_{3}\right]$ range of $30-59 \mathrm{ppb}$. For example, shoot biomass, individual grain weight, and grain yield were significantly decreased by more than $10 \%$ relative to $\mathrm{CF}$ (Fig. 5), which is consistent with lower carbon fixation capacity, indicated as a large decrease in $A_{\text {sat }}(-37 \%)$, chlorophyll concentration (-53\%), and $F_{\mathrm{v}} / F_{\mathrm{m}}$ (Fig. 5). This range of $\left[\mathrm{O}_{3}\right]$ can be found in many locations currently during the wheat-growing season.

\section{Effect of leaf ozone exposure duration}

To clarify if leaf exposure days affected the response of wheat to elevated $\left[\mathrm{O}_{3}\right]$, we classified data reported by

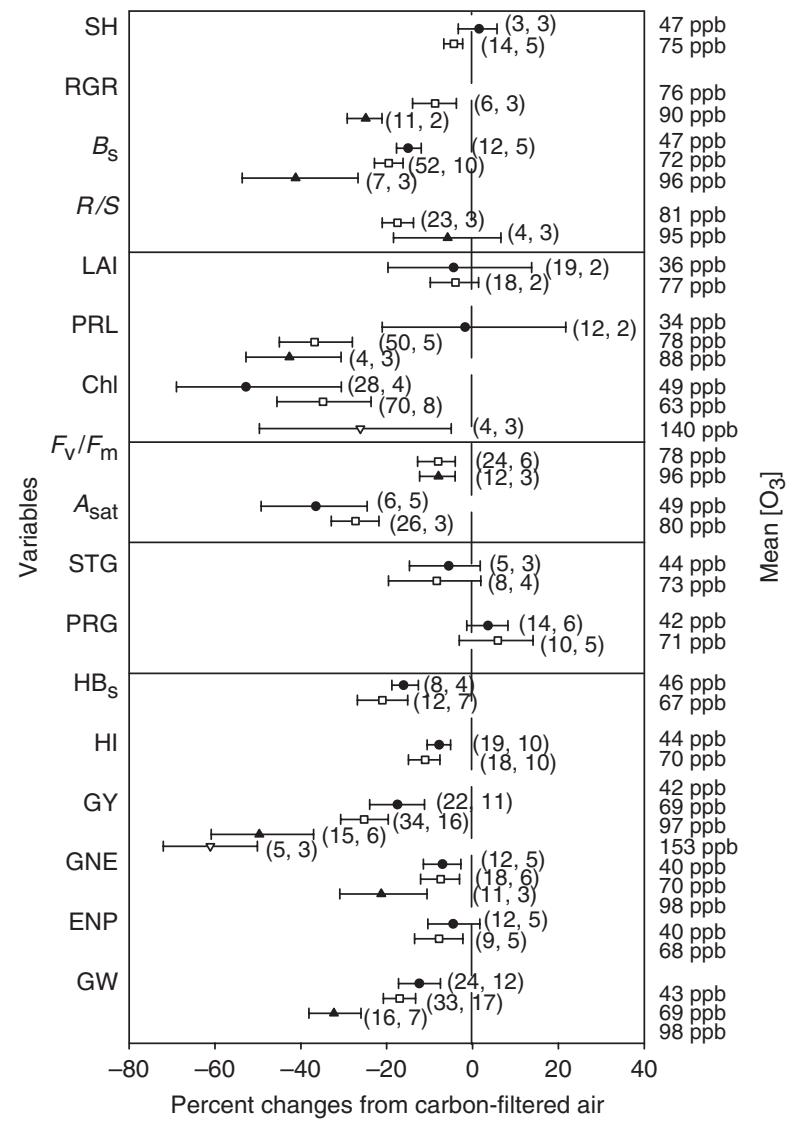

Fig. 5 Effects of different concentrations of elevated $\left[\mathrm{O}_{3}\right]$ 30-59 ppb; $\square: 60-89 \mathrm{ppb}$; $\mathbf{\Lambda}: 90-119 \mathrm{ppb}$; and $\nabla: \geq 120 \mathrm{ppb)}$ on wheat, excluding studies that involved additional treatments. Number of measurements and studies are shown in parentheses, respectively, and average $\left[\mathrm{O}_{3}\right]$ is given on the $y$-axis. Abbreviations for the parameters are described in Table 1.

original papers into four categories. There was a progressive decrease with increasing duration of leaf exposure to elevated $\left[\mathrm{O}_{3}\right]$ in leaf photosynthetic rate, stomatal conductance, and chlorophyll concentration, with few exceptions (Fig. 6), which suggested significant $\mathrm{O}_{3}$ accumulation effects.

\section{Effect of developmental stage}

All variables showed the largest decrease in the grainfilling stage, suggesting either accumulation of $\mathrm{O}_{3}$ damage over the growing season or a higher sensitivity of wheat plants to $\mathrm{O}_{3}$ during this stage. There was a progressive decrease with wheat development and significant difference between stages in photosynthesis rate, leaf chlorophyll, and protein contents when wheat was exposed to elevated $\left[\mathrm{O}_{3}\right]$ (Fig. 7). 


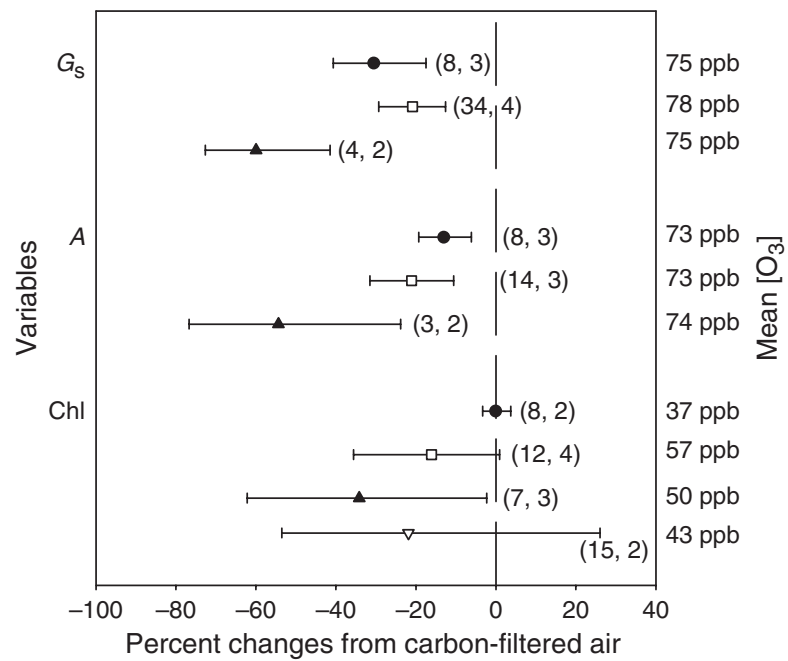

Fig. 6 Response of wheat leaf to elevated $\left[\mathrm{O}_{3}\right]$ at different exposure durations ( $\bullet$ : 3-10 days; $\square$ : 11-20 days; $\mathbf{\Delta}: 21-30$ days; and $\nabla:>30$ days), excluding studies that involved additional treatments. Only studies that reported leaf exposure days are included. Number of measurements and studies are shown in parentheses, respectively, and average $\left[\mathrm{O}_{3}\right]$ is given on the $y$-axis. Abbreviations for the parameters are described in Table 1.

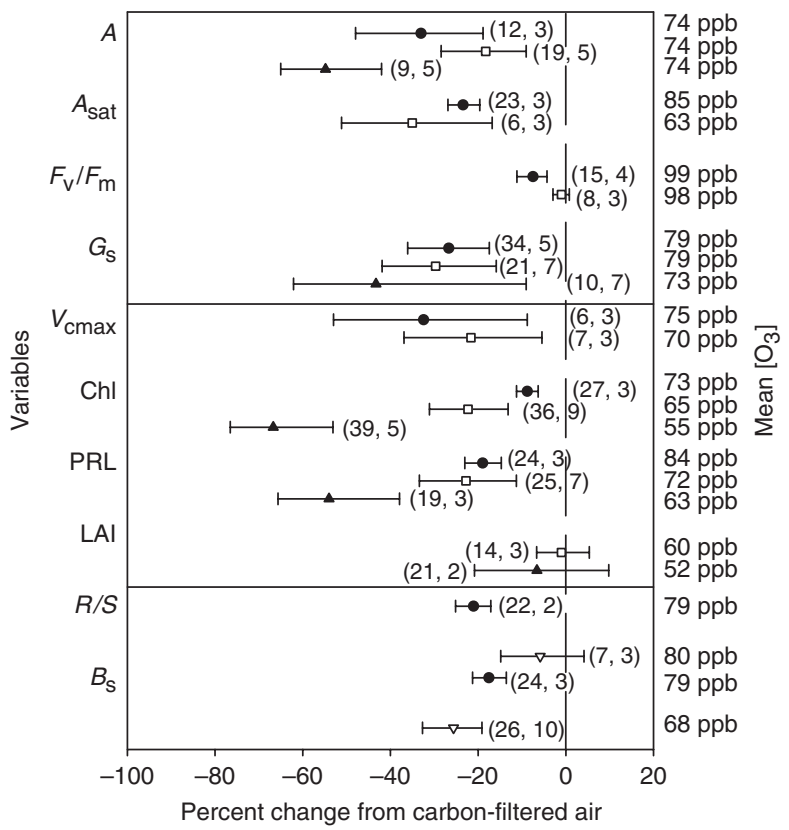

Fig. 7 Response of wheat to elevated $\left[\mathrm{O}_{3}\right]$ at different developmental stages, excluding studies that involved additional treatments. Developmental stages include seedling $(\bullet)$, from booting to anthesis $(\square)$, grain filling $(\boldsymbol{\Lambda})$, and maturity $(\nabla)$. Only studies that reported developmental stage data are included. Number of measurements and studies are shown in parentheses, respectively, and average $\left[\mathrm{O}_{3}\right]$ is given on the $y$ axis. Abbreviations for the parameters are described in Table 1.

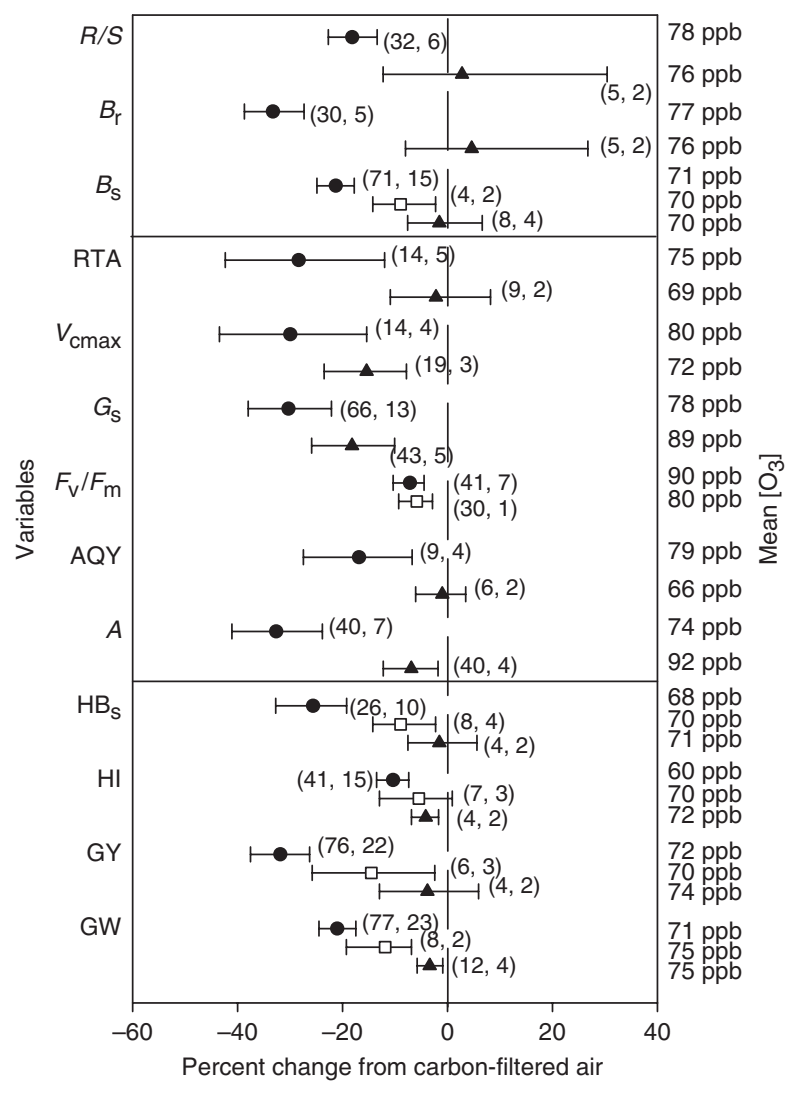

Fig. 8 Interactive effect of elevated $\left[\mathrm{O}_{3}\right]$ on wheat with no additional treatments $(\bullet)$, with drought treatment $(\square)$, and with elevated $\left[\mathrm{CO}_{2}\right](>500 \mathrm{ppm})$ treatment $(\mathbf{\Lambda})$. Number of measurements and studies are shown in parentheses, respectively, and average $\left[\mathrm{O}_{3}\right]$ is given on the $y$-axis. Abbreviations for the parameters are described in Table 1.

\section{Effect of drought and elevated $\left[\mathrm{CO}_{2}\right]$}

Across all studies of the interaction between elevated $\left[\mathrm{O}_{3}\right]$ and additional treatments, most focused on elevated $\left[\mathrm{CO}_{2}\right]$ or drought; therefore, studies were grouped into three categories: those with no additional treatments, studies with combined drought treatments and elevation of $\left[\mathrm{O}_{3}\right]$, and studies with the combined elevation of $\left[\mathrm{O}_{3}\right]$ and $\left[\mathrm{CO}_{2}\right]$ (Fig. 8). For those studies with no additional treatments, elevated $\left[\mathrm{O}_{3}\right]$ induced more than a 15\% decrease in yield parameters, growth, and photosynthesis, with an $\left[\mathrm{O}_{3}\right]$ range from 60 to $90 \mathrm{ppb}$ (Fig. 8), which is in accordance with average decrease across all studies (Fig. 1). Elevated $\left[\mathrm{CO}_{2}\right]$ significantly ameliorated or moderated the deleterious effects of $\mathrm{O}_{3}$ for most parameters (Fig. 8). For example, reduction of leaf photosynthetic rate induced by elevated $\left[\mathrm{O}_{3}\right]$ was lessened by $79 \%$ under elevated $\left[\mathrm{CO}_{2}\right]$ relative to ambient $\left[\mathrm{CO}_{2}\right]$, which mainly resulted from a significant decrease in the ozone impacts on $V_{\text {cmax }}$ 
(49\%) and stomatal conductance (50\%). Based on the mean effect, water stress also lessened the effect of ozone on wheat, as shown in the significantly smaller losses of yield and aboveground biomass (Fig. 8).

\section{Discussion}

To what extent is the grain yield of wheat reduced by elevated $\left[\mathrm{O}_{3}\right]$, and which parameters are associated with the yield reduction?

Numerous studies have shown that seed and fruit yields are commonly reduced in a wide range of agricultural and native species, not only when $\mathrm{O}_{3}$ levels are experimentally increased, but also by the prevailing $\mathrm{O}_{3}$ climate in many parts of the world (reviews: Black et al., 2000; Fuhrer \& Booker, 2003; Ashmore, 2005). This meta-analytic evaluation of peer-reviewed literature indicates that the increase of surface $\left[\mathrm{O}_{3}\right]$ decreased wheat grain yield by $29 \%(n=90)$, with a $95 \%$ CI of $24-34 \%$ in spite of the variation in the response observed between studies. The average 7 or $8-\mathrm{h}\left[\mathrm{O}_{3}\right]$ was $72 \mathrm{ppb}$, with a range of $30-200 \mathrm{ppb}$, across all the reported studies on effects of chronic $\mathrm{O}_{3}$ treatment. The exposure-response relationship allowed the yield losses for different crops to be estimated for a given $\mathrm{O}_{3}$ exposure (Ashmore, 2002). For a seasonal 7-h mean $\left[\mathrm{O}_{3}\right]$ of $72 \mathrm{ppb}$, the estimated yield reduction for wheat was $31 \%$ based on the linear dose-response model (Mills et al., 2000), suggesting an agreement between the two methods. The yield losses induced by different levels of $\left[\mathrm{O}_{3}\right]$ were within the range of estimates by doseresponse relationship (Mills et al., 2000), with an exception of the highest level $\left[\mathrm{O}_{3}\right]$, which exceeded the upper limit (ca.125 ppb) of the dose-response equation.

From our meta-analysis, the most important yield component responsible for grain yield reduction was the decrease in individual grain weight, although both ears per plant and grains per ear showed significant decreases at elevated $\left[\mathrm{O}_{3}\right]$. It is suggested that, among the growth processes, grain filling was damaged most by elevated $\left[\mathrm{O}_{3}\right]$. It is unclear, however, if this is because of the higher ozone sensitivity at the growth stage, or simply because of the accumulation of ozone damages through to this stage, as mentioned later. Similar results have been reported in many studies with wheat (Fuhrer et al., 1989; Feng et al., 2007), barley and rape (Adaros et al., 1991), and bean (P. vulgaris) (Sanders et al., 1992).

Yield loss has often been attributed to reduction in photosynthetic activity and to lower supply of assimilates that support reproductive development and seed growth (Black et al., 2000; Fiscus et al., 2005). Our results supported this reasoning, coupling a reduction of $20 \%$ in photosynthetic rate and that of $18 \%$ in aboveground biomass. From this analysis, the decrease in the Rubisco activity (20\%) coincided with the reduction in $A_{\text {sat, }}$ suggesting that lower Rubisco activity is the prevailing cause of lost photosynthetic rate induced by elevated $\left[\mathrm{O}_{3}\right]$. This agrees with the results in $\mathrm{O}_{3}$-exposed leaves of Plantago major (Zheng et al., 2002).

Are wheat responses to $\mathrm{O}_{3}$ dependent on growth stages, wheat type, fumigation method, and rooting environment?

Growth stages. From the analysis of published data on gas exchange and leaf chemistry, we found a progressive decrease in most parameters with developmental stage (Fig. 7), in agreement with the results of a meta-analysis on soybean (Morgan et al., 2003). This could be explained by cumulative effects that build over the growing season. But these results could also be explained by a greater sensitivity in the later stages of development. Most studies of the effects of $\mathrm{O}_{3}$ on the performance of agricultural crops have involved exposure from vegetative to reproductive stages, making it impossible to distinguish direct effects, if any, of the latter developmental stage from indirect effects accumulated from the vegetative stages via injury to the vegetative organs and alterations in the production and partitioning of assimilates (Black et al., 2000). Pleijel et al. (1998) exposed field-grown spring wheat to the same $\mathrm{O}_{3}$ dose ( $2500 \mathrm{ppb}$ h above $40 \mathrm{ppb}$ ) before and after the onset of anthesis, and reported that $\mathrm{O}_{3}$ exposure is much more effective in decreasing the grain yield after than before the anthesis. Similar results were also found in bean (Younglove et al., 1994). However, due to limited sample size, we could not test if leaves are more sensitive to $\mathrm{O}_{3}$ after anthesis than before anthesis in this meta-analysis.

Other factors. Another important factor determining the variation in wheat to elevated $\left[\mathrm{O}_{3}\right]$ is the type of ozone exposure. Plants exposed to elevated $\left[\mathrm{O}_{3}\right]$ in OTCs showed larger decreases in most parameters than those in indoor growth chambers, although significant differences were only detected in individual grain weight, harvest index, and leaf protein concentration (Fig. 3). This can be explained by the fact that wheat plants grown in indoor growth chambers are more ozone resistant than those in OTCs, as the former are characterized by lower stomatal density and lower stomatal conductance due to lower effective light (Oksanen et al., 2005). Similar phenomenon was also found in trees response to elevated $\left[\mathrm{O}_{3}\right]$ (Valkama et al., 2007; Wittig et al., 2007). On the other hand, plants in OTC are better coupled with the surrounding air than those in the field, and hence the former plants take up 
$\mathrm{O}_{3}$ at a higher rate than the latter ones under the same $\left[\mathrm{O}_{3}\right]$ (Nussbaum \& Fuhrer, 2000). It is unclear, however, if the plants in indoor chambers are less coupled with the air than those in OTC.

It was assumed that the response of spring wheat to elevated $\left[\mathrm{O}_{3}\right]$ was different from that of winter wheat. A prior comparison of OTC experiments in Europe and USA showed that European spring cultivars are more sensitive than North American winter cultivars when exposed to a 7-8h seasonal mean of $60-120 \mathrm{ppb} \mathrm{O}_{3}$ (Miller, 1993). However, our meta-analysis across all studies excluding additional treatments indicated that there was no significant difference between spring wheat and winter wheat in response to elevated $\left[\mathrm{O}_{3}\right]$ in terms of investigated parameters, with the exception of stomatal conductance, although the average $\left[\mathrm{O}_{3}\right]$ in winter wheat was higher than that in spring wheat. Similar results were also found in the study of Mills et al. (2007), where there were no statistical differences in the slope of the response relationship between relative yield and AOT40 for European and USA cultivars of wheat grown in the field.

\section{Does elevated $\left[\mathrm{CO}_{2}\right]$ or drought modify the effects of elevated $\left[\mathrm{O}_{3}\right]$ on wheat growth?}

The detrimental effects of $\mathrm{O}_{3}$ vary with flux into the mesophyll via the stomata; therefore, a popular notion is that any environmental factors that decrease stomatal conductance will decrease flux of $\mathrm{O}_{3}$ into intercellular spaces of the leaf. It is well documented that high vapor pressure deficit, drought, and elevated $\left[\mathrm{CO}_{2}\right]$ decrease stomatal conductance. Consequently, it may be expected that the decrease in photosynthesis or biomass growth caused by $\mathrm{O}_{3}$ exposure will be less under stress conditions than under nonstress conditions (Morgan et al., 2003; Fiscus et al., 2005; Wittig et al., 2007). This notion was supported by our analysis. Elevated $\left[\mathrm{CO}_{2}\right]$ significantly ameliorated the large decrease in stomatal conductance induced by elevated $\left[\mathrm{O}_{3}\right]$ (Fig. 8), implying that $\mathrm{O}_{3}$ flux into leaves was reduced significantly and thus the damage to the photosynthetic apparatus was limited when elevated $\left[\mathrm{CO}_{2}\right]$ was present. Our result was consistent with Wittig et al. (2007) who investigated the effects of elevated $\left[\mathrm{CO}_{2}\right]$ on the response of stomatal conductance of trees to elevated $\left[\mathrm{O}_{3}\right]$. However, a metaanalysis on soybean indicated that elevated $\left[\mathrm{CO}_{2}\right]$ significantly increased the reduction in stomatal conductance induced by elevated $\left[\mathrm{O}_{3}\right]$, relative to ambient $\left[\mathrm{CO}_{2}\right]$ (Morgan et al., 2003). Vandermeiren et al. (2002) examined the results with potato in OTCs at many experimental sites from the European CHIP-program and concluded that elevated $\left[\mathrm{CO}_{2}\right]$ counteracted the adverse effect of elevated $\left[\mathrm{O}_{3}\right]$ on photosynthesis via a reduction in stomatal conductance.

In accordance with smaller reduction in stomatal conductance, the mean decrease in photosynthetic rate was $7 \%$ in the combination of elevated $\left[\mathrm{CO}_{2}\right]$ and $\left[\mathrm{O}_{3}\right]$, compared with a $33 \%$ loss for wheat grown at elevated $\left[\mathrm{O}_{3}\right]$ and current $\left[\mathrm{CO}_{2}\right]$ (Fig. 8). This is in agreement with the meta-analysis of soybean (Morgan et al., 2003). Foliar damage was significantly reduced as reported by Mulholland et al. (1998). Accordingly, biomass and grain yield losses were partially or completely ameliorated by elevated $\left[\mathrm{CO}_{2}\right]$ in wheat. The decrease in aboveground biomass, grain yield, and harvest index for plants grown in elevated $\left[\mathrm{CO}_{2}\right]$ and $\left[\mathrm{O}_{3}\right]$ is $84 \%$, $88 \%$, and $60 \%$ less than those grown in current $\left[\mathrm{CO}_{2}\right]$ and elevated $\left[\mathrm{O}_{3}\right]$, respectively (Fig. 8). Similarly, elevated $\left[\mathrm{O}_{3}\right]$ reduced positive effects of elevated $\left[\mathrm{CO}_{2}\right]$ on the yield, as indicated in the review of Amthor (2001) who synthesized the effects of atmospheric $\left[\mathrm{CO}_{2}\right]$ on wheat yield across five different methods of controlling $\left[\mathrm{CO}_{2}\right]$. However, in elevated $\left[\mathrm{O}_{3}\right]$, biomass and yield of most crops were increased significantly under elevated $\left[\mathrm{CO}_{2}\right]$ but the variability of the responses remained large or even opposite (e.g. inhibition by $\mathrm{O}_{3}$ was altered little by $\mathrm{CO}_{2}$ enrichment for some highly $\mathrm{O}_{3}$-susceptible lines of potato and snap bean (Heagle et al., 2002, 2003). Similarly, water stress significantly modified the decrease in aboveground biomass and yield induced by elevated $\left[\mathrm{O}_{3}\right]$, but did not alter the change in individual grain weight, ears per plant, and harvest index caused by elevated $\left[\mathrm{O}_{3}\right]$, which suggested that water stress may ameliorate the decrease in grains per ear. However, in some studies, no clear interactions were also observed between ozone and water stress (Temple, 1986; Fangmeier et al., 1994).

To what extent do current ambient and future $\left[\mathrm{O}_{3}\right]$ affect wheat yield?

Given current emission trends, tropospheric $\left[\mathrm{O}_{3}\right]$ is projected to rise globally by $20-25 \%$ between 2015 and 2050, and $40-60 \%$ by 2100 (Meehl et al., 2007). Therefore, projections imply an increase in $\left[\mathrm{O}_{3}\right]$ from a current $40 \mathrm{ppb}$ to $48-50 \mathrm{ppb}$ by 2050 and to $56-64 \mathrm{ppb}$ by 2100 for temperate regions of the Northern hemisphere (Wittig et al., 2007). In our meta-analysis, the average for the $\left[\mathrm{O}_{3}\right]$ range from 30 to $50 \mathrm{ppb}$ was $43 \mathrm{ppb}$ (Level A), and that for the $\left[\mathrm{O}_{3}\right]$ range from 62 to $82 \mathrm{ppb}$ was $73 \mathrm{ppb}$ (Level B). We can assume that Level A represents current ambient $\left[\mathrm{O}_{3}\right]$, and that Level $\mathrm{B}$ represents future $\left[\mathrm{O}_{3}\right]$. Although the Level $\mathrm{B}\left[\mathrm{O}_{3}\right]$ is higher than the projection, the 7-h mean $\left[\mathrm{O}_{3}\right]$ during wheat growth is more than $70 \mathrm{ppb}$ in many developed countries and in some parts of developing countries in Asia (Wahid et al., 
1995; Benton et al., 2000; Wang \& Mauzerall, 2004; Wang et al., 2005). Our results indicated that current ambient $\left[\mathrm{O}_{3}\right]$ is depressing grain yield in wheat by $17.5 \%$, with a $95 \%$ CI of $-11 \%$ to $-24 \%$ (Fig. 5), which is in agreement with the dose-response estimates (Mills et al., 2000). This is based on 22 independent measurements across 10 cultivars and seven countries excluding all additional treatments. The wheat yield loss is clearly higher than average seed yield loss in soybean (10\%) (Morgan et al., 2003), which was largely driven by a decrease (37\%) in $A_{\text {sat }}$. Yield loss at ambient $\left[\mathrm{O}_{3}\right]$ in crops has already occurred in most countries in Europe according to the investigation of UN/ECE ICP-Vegetation Project (Benton et al., 2000). Based on this current meta-analysis, future surface $\left[\mathrm{O}_{3}\right]$ could drive a further decrease in yield relative to current $\left[\mathrm{O}_{3}\right]$ (Fig. 5). However, $\mathrm{O}_{3}$ is not the only element of global change, and it will interact with other factors such as drought stress, increasing $\left[\mathrm{CO}_{2}\right]$, and temperature.

\section{Acknowledgements}

We acknowledge Drs Don R. Ort and Victoria E. Wittig of the University of Illinois at Urbana-Champaign for their helpful comments. This study was supported by Eco-Frontier Fellowship (07-C062-03) and the Global Environment Research Fund (C-062) of the Ministry of Environment, Japan.

\section{References}

Adams DC, Gurevitch J, Rosenberg MS (1997) Resampling tests for meta-analysis of ecological data. Ecology, 78, 1277-1283.

Adaros GA, Weigel HJ, Jager HJ (1991) Growth and yield of spring rape and spring barley as affected by chronic ozone stress. Journal of Plant Diseases and Protection, 98, 513-525.

Ainsworth EA (2008) Rice production in a changing climate: a meta-analysis of responses to elevated carbon dioxide and elevated ozone concentration. Global Change Biology, 14, 16421650.

Ainsworth EA, Davey PA, Bernacchi CJ et al. (2002) A metaanalysis of elevated $\left[\mathrm{CO}_{2}\right]$ effects on soybean (Glycine max) physiology, growth and yield. Global Change Biology, 8, 695-709.

Ainsworth EA, Long SP (2005) What have we learned from 15 years of free-air $\mathrm{CO}_{2}$ enrichment (FACE)? A meta-analytic review of the responses of photosynthesis, canopy properties and plant production to rising $\mathrm{CO}_{2}$. New Phytologist, 165, 351-371.

Amthor JS (2001) Effects of atmospheric $\mathrm{CO}_{2}$ concentration on wheat yield: review of results from experiments using various approaches to control $\mathrm{CO}_{2}$ concentration. Field Crops Research, 73, 1-34.

Ashmore MR (2002) Effects of oxidants at the whole plant and community level. In: Air Pollution and Plants (ed. Treshow M), pp. 89-118. John Wiley, London, UK.

Ashmore MR (2005) Assessing the future global impacts of ozone on vegetation. Plant, Cell and Environment, 28, 949-964.
Benton J, Fuhrer J, Gimeno BS et al. (2000) An international cooperative programme indicates the widespread occurrence of ozone injury on crops. Agriculture, Ecosystems and Environment, 78, 19-30.

Black VJ, Black CR, Roberts JA, Stewart CA (2000) Impact of ozone on the reproductive development of plants. New Phytologist, 147, 421-447.

Booker FL (2004) Influence of ozone on ribonuclease activity in wheat (Triticum aestivum) leaves. Physiologia Plantarum, 120, 249-255.

Clarke BB, Greenhalgh-Weidman B, Brennan EG (1990) An assessment of the impact of ambient ozone on field-grown crops in New Jersey using the EDU method: Part 1 - White potato (Solanum tuberosum). Environmental Pollution, 66, 351-360.

Curtis PS, Wang X (1998) A meta-analysis of elevated $\mathrm{CO}_{2}$ effects on woody plant mass, form, and physiology. Oecologia, 113, 299-313.

EPA US (2006) Air Quality Criteria for Ozone and Related Photochemical Oxidants (Final). US Environmental Protection Agency, Washington, DC, USA.

Ewert F, Pleijel H (1999) Phenological development, leaf emergence, tillering and leaf area index, and duration of spring wheat across Europe in response to $\mathrm{CO}_{2}$ and ozone. European Journal of Agronomy, 10, 171-184.

Fangmeier A, Brockerhoff U, Grüters U, Jäger HJ (1994) Growth and yield responses of spring wheat (Triticum aestivum L., cv. Turbo) grown in open-top chambers to ozone and water stress. Environmental Pollution, 83, 317-325.

FAO (2007) Statistical database. No. 4, July 2007. www.fao.org. Feng ZW, Jin MH, Zhang FZ, Huang YZ (2003) Effects of groundlevel ozone $\left(\mathrm{O}_{3}\right)$ pollution on the yields of rice and winter wheat in the Yangtze River Delta. Journal of Environmental Science (China), 15, 360-362.

Feng ZZ, Yao FF, Chen Z, Wang XK, Zheng QW, Feng ZW (2007) Response of gas exchange and yield components of fieldgrown Triticum aestivum L. to elevated ozone in China. Photosynthetica, 45, 441-446.

Finnan JM, Jones MB, Burke JI (1998) A time-concentration study on the effects of ozone on spring wheat (Triticum aestivum L.). 3. Effects on leaf area and flag leaf senescence. Agriculture, Ecosystems and Environment, 69, 27-35.

Fiscus EL, Booker FL, Burkey KO (2005) Crop responses to ozone: uptake, modes of action, carbon assimilation and partitioning. Plant, Cell and Environment, 28, 997-1011.

Fowler D, Cape JN, Coyle M et al. (1999a) The global exposure of forests to air pollutants. Water, Air, and Soil Pollution, 116, 5-32.

Fowler D, Cape JN, Coyle M et al. (1999b) Modelling photochemical oxidant formation, transport, deposition and exposure of terrestrial ecosystems. Environmental Pollution, 100, 43-55.

Fuhrer J, Booker F (2003) Ecological issues related to ozone: agricultural issues. Environment International, 29, 141-154.

Fuhrer J, Egger A, Lehnherr B, Grandjean A, Tschannen W (1989) Effects of ozone on the yield of spring wheat (Triticum aestivum L., cv. Albis) grown in open-top field chambers. Environmental Pollution, 60, 273-289.

Gurevitch J, Hedges LV (1999) Statistical issues in ecological meta-analyses. Ecology, 80, 1142-1149. 
Heagle AS (1989) Ozone and crop yield. Annual Review of Phytopathology, 27, 397-423.

Heagle AS, Miller JE, Burkey KO, Eason G, Pursley WA (2002) Growth and yield responses of snap bean to mixtures of carbon dioxide and ozone. Journal of Environmental Quality, 31, 2008-2014.

Heagle AS, Miller JE, Pursley WA (2003) Growth and yield responses of potato to mixtures of carbon dioxide and ozone. Journal of Environmental Quality, 32, 1603-1610.

Hedges LV, Gurevitch J, Curtis PS (1999) The meta-analysis of response ratios in experimental ecology. Ecology, 80, 1150-1156.

Karnosky D, Skelly J, Percy K, Chappelka A (2007) Prospectives regarding 50 years of research on effects of tropospheric ozone air pollution on US forests. Environmental Pollution, 147, 489-506.

Khan S, Soja G (2003) Yield responses of wheat to ozone exposure as modified by drought-induced differences in ozone uptake. Water, Air, and Soil Pollution, 147, 299-315.

Kobayashi K, Okada M (1995) Effects of ozone on the light use of rice (Oryza sativa L.) plants. Agriculture, Ecosystems and Environment, 53, 1-12.

Kobayashi K, Okada M, Nouchi I (1995) Effects of ozone on dry matter partitioning and yield of Japanese cultivars of rice (Oryza sativa L.). Agriculture, Ecosystems and Environment, 53, 109-122.

Kollner B, Krause GHM (2003) Effects of two different ozone exposure regimes on chlorophyll and sucrose contents of leaves and yield parameters of sugar beet (Beta Vulgaris L.) and rape (Brassica Napus L.). Water, Air, and Soil Pollution, 144, 317-332.

Krupa S, McGrath MT, Andersen CP et al. (2001) Ambient ozone and plant health. Plant Disease, 85, 4-12.

Lee EH, Tingey DT, Hogsett WE (1988) Evaluation of ozone exposure indices in exposure-response modelling. Environmental Pollution, 53, 43-62.

Long SP, Naidu SL (2002) Effects of oxidants at the biochemical, cell and physiological levels. In: Air Pollution and Plants (ed. Treshow M), pp. 69-88. John Wiley, London, UK.

Meehl GA, Stocker TF, Collins WD et al. (eds) (2007) Global Climate Projections. Cambridge University Press, Cambridge, UK/New York, NY, USA.

Miller JE (1993) Responses of plant yield to $\mathrm{O}_{3}$, a discussion of EOTC and NCLAN protocols and results. In: Effects of Air Pollution on Agricultural Crops in Europe. Results of the European Open-Top Chamber Project (eds Jager HJ, Unsworth MH, De Temmerman L, Mathy P), pp. 213-229. Air pollution research report series of European Communities, No. 46, Commission of the European Communities, Luxembourg.

Mills G, Buse A, Gimeno B, Bermejo V, Holland M, Emberson L, Pleijel H (2007) A synthesis of AOT40-based response functions and critical levels of ozone for agricultural and horticultural crops. Atmospheric Environment, 41, 2630-2643.

Mills G, Hayes F, Buse A, Reynolds B (2000) Air pollution and vegetation. Annual Report 1999/2000 of UN/ECE ICP Vegetation, Centre for Ecology and Hydrology, Bangor, UK.

Mittal ML, Hess PG, Jain SL, Arya BC, Sharma C (2007) Surface ozone in the Indian region. Atmospheric Environment, 41, 6572-6584.
Morgan PB, Ainsworth EA, Long SP (2003) How does elevated ozone impact soybean? A meta-analysis of photosynthesis, growth and yield. Plant, Cell and Environment, 26, 1317-1328.

Mulholland BJ, Craigon J, Black CR, Colls JJ, Atherton J, Landon G (1998) Growth, light interception and yield response of spring wheat (Triticum aestivum L.) to elevated $\mathrm{CO}_{2}$ and $\mathrm{O}_{3}$ in open-top chambers. Global Change Biology, 4, 121-130.

Nali C, Pucciariello C, Lorenzini G (2002) Ozone distribution in central Italy and its effect on crop productivity. Agriculture, Ecosystems and Environment, 90, 277-289.

Nouchi I, Osamu I, Harazono Y, Kouchi H (1995) Acceleration of ${ }^{13} \mathrm{C}$-labelled photosynthate partitioning from leaves to panicles in rice plants exposed to chronic ozone at the reproductive stage. Environmental Pollution, 88, 253-260.

Nussbaum S, Fuhrer J (2000) Difference in ozone uptake in grassland species between open-top chambers and ambient air. Environmental Pollution, 109, 463-471.

Ojanpera K, Patsikka E, Ylaranta T (1998) Effects of low ozone exposure of spring wheat on net $\mathrm{CO}_{2}$ uptake, Rubisco, leaf senescence and grain filling. New Phytologist, 138, 451-460.

Oksanen E, Riikonen J, Kaakinen S, Holopainen T, Vapaavuori E (2005) Structural characteristics and chemical composition of birch (Betula pendula) leaves are modified by increasing $\mathrm{CO}_{2}$ and ozone. Global Change Biology, 11, 732-748.

Pleijel H, Danielsson H, Gelang J, Sild E, Selldén G (1998) Growth stage dependence of the grain yield response to ozone in spring wheat (Triticum aestivum L.). Agriculture, Ecosystems and Environment, 70, 61-68.

Rosenberg MS, Adams DC, Gurevitch J (2000) Metawin: Statistical Software for Meta-Analysis, Version 2.1. Sinauer Associates, Inc, Sunderland, MA, USA.

Sanders GE, Coils JJ, Clark AG, Galaup S, Bonte J, Cantuel J (1992) Phaseolus vulgaris and ozone: results from open-top chamber experiments in France and England. Agriculture, Ecosystems and Environment, 38, 31-40.

Singh RP, Huerta-Espino J, Sharma R, Joshi AK, Trethowan R (2007) High yielding spring bread wheat germplasm for global irrigated and rainfed production systems. Euphytica, 157, 351-363.

Temple PJ (1986) Stomatal conductance and transpirational responses of field-grown cotton to ozone. Plant, Cell and Environment, 9, 315-321.

Valkama E, Koricheva J, Oksanen E (2007) Effects of elevated $\mathrm{O}_{3}$, alone and in combination with elevated $\mathrm{CO}_{2}$, on tree leaf chemistry and insect herbivore performance: a meta-analysis. Global Change Biology, 13, 184-201.

Vandermeiren K, Black C, Lawson T, Casanova MA, Ojanpera K (2002) Photosynthetic and stomatal responses of potatoes grown under elevated $\mathrm{CO}_{2}$ and/or $\mathrm{O}_{3}$ - results from the European CHIP-programme. European Journal of Agronomy, 17, 337-352.

Vingarzan R (2004) A review of surface ozone background levels and trends. Atmospheric Environment, 38, 3431-3442.

Wahid A, Maggs R, Shamsi SRA, Bell JNB, Ashmore MR (1995) Air pollution and its impacts on wheat yield in the Pakistan Punjab. Environmental Pollution, 88, 147-154. 
Wang HX, Kiang CS, Tang XY, Zhou XJ, Chameides WL (2005) Surface ozone: a likely threat to crops in Yangtze Delta of China. Atmospheric Environment, 39, 3843-3850.

Wang X, Mauzerall DL (2004) Characterising distributions of surface ozone and its impacts on grain production in China, Japan and South Korea. Atmospheric Environment, 38, 4383-4402.

Wang XK, Manning WJ, Feng ZW, Zhu YG (2007a) Ground-level ozone in China: distribution and effects on crop yields. Environmental Pollution, 147, 394-400.

Wang XK, Zheng QW, Yao FF, Chen Z, Feng ZZ, Manning WJ (2007b) Assessing the impact of ambient ozone on growth and yield of a rice (Oryza sativa L.) and a wheat (Triticum aestivum L.) cultivar grown in the Yangtze Delta, China, using three rates of application of ethylenediurea (EDU). Environmental Pollution, 148, 390-395.

Wittig VE, Ainsworth EA, Long SP (2007) To what extent do current and projected increases in surface ozone affect photosynthesis and stomatal conductance of trees? A meta-analytic review of the last 3 decades of experiments. Plant, Cell and Environment, 30, 1150-1162.

Younglove T, McCool PM, Musselman RC, Kahl ME (1994) Growth-stage dependent crop yield response to ozone exposure. Environmental Pollution, 86, 287-285.

Zheng Y, Shimizu H, Barnes JD (2002) Limitations to $\mathrm{CO}_{2}$ assimilation in ozone-exposed leaves of Plantago major. New Phytologist, 155, 67-78.

\section{Appendix A. Articles used in meta-analysis of elevated ozone effects}

Adaros G, Weigel HJ, Jager HJ (1991) Impact of ozone on growth and yield parameters of two spring wheat cultivars (Triticum aestivum L.). Journal of Plant Diseases and Protection, 98, 113-124.

Balaguer L, Barnes JD, Panicucci A, Borland AM (1995) Production and utilization of assimilates in wheat (Triticum aestivum L.) leaves exposed to elevated $\mathrm{O}_{3}$ and/or $\mathrm{CO}_{2}$. New Phytologist, 129, 557-568.

Barnes JD, Velissariou D, Davison AW, Holevas CD (1990) Comparative ozone sensitivity of old and modern Greek cultivars of spring wheat. New Phytologist, 116, 707-714.

Bender J, Weigel HJ, Wegner U, Jager HJ (1994) Response of cellular antioxidants to ozone in wheat flag leaves at different stages of plant development. Environmental Pollution, 84, 15-21.

Biswas DK, Xu H, Li YG, Sun JZ, Wang XZ, Han XG, Jiang GM (2008) Genotypic differences in leaf biochemical, physiological and growth responses to ozone in 20 winter wheat cultivars released over the past 60 years. Global Change Biology, 14, 46-59.

Booker FL (2004) Influence of ozone on ribonuclease activity in wheat (Triticum aestivum L.) leaves. Physiologia Plantarum, 120, 249-255.

Cardoso-Vilhena J, Balaguer L, Eamus D, Ollerenshaw J, Barnes J (2004) Mechanisms underlying the amelioration of $\mathrm{O}_{3}$-induced damage by elevated atmospheric concentrations of $\mathrm{CO}_{2}$. Journal of Experimental Botany, 55, 771-781.
Cardoso-Vilhena J, Barnes J (2001) Does nitrogen supply affect the response of wheat (Triticum aestivum L. cv. Hanno) to the combination of elevated $\mathrm{CO}_{2}$ and $\mathrm{O}_{3}$ ? Journal of Experimental Botany, 52, 1901-1911.

Fangmeier A, Brockerhoff U, Gruters U, Jager HJ (1994) Growth and yield responses of spring wheat (Triticum aestivum $\mathrm{L} . \mathrm{cv}$. Turbo) grown in open-top chambers to ozone and water stress. Environmental Pollution, 83, 317-325.

Fangmeier A, Brunschon S, Jager HJ (1994) Time course of oxidant stress biomarkers in flag leaves of wheat exposed to ozone and drought stress. New Phytologist, 126, 63-69.

Farage PK, Long SP (1999) The effects of $\mathrm{O}_{3}$ fumigation during leaf development on photosynthesis of wheat and pea: an in vivo analysis. Photosynthesis Research, 59, 1-7.

Feng ZW, Jin MH, Zhang FZ, Huang YZ (2003) Effects of groundlevel ozone $\left(\mathrm{O}_{3}\right)$ pollution on the yields of rice and winter wheat in the Yangtze River Delta. Journal of Environmental Science, 15, 360-362.

Feng ZZ, Yao FF, Chen Z, Wang XK, Zheng QW, Feng ZW (2007) Response of gas exchange and yield components of fieldgrown Triticum aestivum L. to elevated ozone in China. Photosynthetica, 45, 441-446.

Finnan JM, Jones MB, Burke JI (1996) A time-concentration study on the effects of ozone on spring wheat (Triticum aestivum L.). 1. Effects on yield. Agriculture, Ecosystems and Environment, 57, 159-167.

Finnan JM, Jones MB, Burke JI (1998) A time-concentration study on the effects of ozone on spring wheat (Triticum aestivum L.). 3. Effects on leaf area and flag leaf senescence. Agriculture, Ecosystems and Environment, 69, 27-35.

Fuhrer J, Egger A, Lehnherr B, Grandjean A, Tschannen W (1989) Effects of ozone on the yield of spring wheat (Triticum aestivum L., cv. Albis) grown in open-top field chambers. Environmental Pollution, 60, 273-289.

Fuhrer J, Grimm GA, Tschannen W, Shariat-Madari H (1992) The response of spring wheat (Triticum aestivum L.) to ozone at higher elevations II. Changes in yield, yield components and grain quality in response to ozone flux. New Phytologist, 121, 211-219.

Fuhrer J, Lehnherr B, Moeri PB, Tschannen W, Shariat-Madari H (1990) Effects of ozone on the grain composition of spring wheat grown in open-top field chambers. Environmental Pollution, 65, 181-192.

Gelang J, Pleijel H, Sild E, Danielsson H, Younis S, Selldén G (2000) Rate and duration of grain filling in relation to flag leaf senescence and grain yield in spring wheat (Triticum aestivum L.) exposed to different concentrations of ozone. Physiologia Plantarum, 110, 366-375.

Gelang J, Selldén G, Younis S, Pleijel H (2001) Effects of ozone on biomass, non-structural carbohydrates and nitrogen in spring wheat with artificially manipulated source/sink ratio. Environmental and Experimental Botany, 46, 155-169.

Grimm GA, Fuhrer J (1989) Growth and leaf senescence in spring wheat (Triticum aestivum L.) grown at different ozone concentrations in open-top field chambers. Physiologia Plantarum, 77, 389-394.

Grimm GA, Fuhrer J (1992a) The response of spring wheat (Triticum aestivum L.) to ozone at higher elevations I. Measure- 
ment of ozone and carbon dioxide fluxes in open-top field chambers. New Phytologist, 121, 201-210.

Grimm GA, Fuhrer J (1992b) The response of spring wheat (Triticum aestivum L.) to ozone at higher elevations III. Responses of leaf and canopy gas exchange, and chlorophyll fluorescence to ozone flux. New Phytologist, 122, 321-328.

Hassan IA (2004) Interactive effects of salinity and ozone pollution on photosynthesis, stomatal conductance, growth, and assimilate partitioning of wheat (Triticum aestivum L.). Photosynthetica, 42, 111-116.

Heagle AS, Miller JE, Pursley WA (2000) Growth and yield responses of winter wheat to mixtures of ozone and carbon dioxide. Crop Science, 40, 1656-1664.

Khan S (2005) Modification of ozone effect on photosynthetic capacity of winter wheat (Triticum aestivum L. cv. Perlo) at different levels of water availability. Water, Air, and Soil Pollution, 160, 197-211

Khan S, Soja G (2003) Yield responses of wheat to ozone exposure as modified by drought-induced differences in ozone uptake. Water, Air, and Soil Pollution, 147, 299-315.

Kress LW, Miller JE, Smith HJ (1985) Impact of ozone on winter wheat yield. Environmental and Experimental Botany, 25, 211-228.

Lehnherr B, Grandjean A, Machler F, Fuhrer J (1987) The effect of ozone in ambient air on ribulosebisphosphate carboxylase/ oxygenase activity decreases photosynthesis and grain yield in wheat. Journal of Plant Physiology, 130, 189-200.

Lehnherr B, Machier F, Grandjean A, Fuhrer J (1988) The regulation of photosynthesis in leaves of field-grown spring wheat (Triticum aestivum L., cv Albis) at different levels of ozone in ambient air. Plant Physiology, 88, 1115-1119.

McKee IF, Bullimore JF, Long SP (1997) Will elevated $\mathrm{CO}_{2}$ concentrations protect the yield of wheat from $\mathrm{O}_{3}$ damage? Plant, Cell and Environment, 20, 77-84.

McKee IF, Farage PK, Long SP (1995) The interactive effects of elevated $\mathrm{CO}_{2}$ and $\mathrm{O}_{3}$ concentration on photosynthesis in spring wheat. Photosynthesis Research, 45, 111-119.

McKee IF, Long SP (2001) Plant growth regulators control ozone damage to wheat yield. New Phytologist, 152, 41-51.

Meyer U, Kollner B, Willenbrink J, Krause GHM (1997) Physiological changes on agricultural crops induced by different ambient ozone exposure regimes I. Effects on photosynthesis and assimilate allocation in spring wheat. New Phytologist, 136, 645-652.

Meyer U, Kollner B, Willenbrink J, Krause GHM (2000) Effects of different ozone exposure regimes on photosynthesis, assimilates and thousand grain weight in spring wheat. Agriculture, Ecosystems and Environment, 78, 49-55.

Mortensen L, Engvild KC (1995) Effects of ozone on ${ }^{14} \mathrm{C}$ translocation velocity and growth of spring wheat (Triticum aestivum L.) exposed in open-top chambers. Environmental Pollution, 87, 135-140.

Mortensen L, Jorgensen HE (1996) Response of spring wheat (Triticum aestivum L.) to ozone produced by either electric discharge and dry air or by UV-lamps and ambient air. Environmental Pollution, 93, 121-127.

Nie GY, Tomasevic M, Baker NR (1993) Effects of ozone on the photosynthetic apparatus and leaf proteins during leaf development in wheat. Plant, Cell and Environment, 16, 643-651.
Nussbaum S, Geissmann M, Fuhrer J (1995) Effect of nitric oxide and ozone on spring wheat (Triticum aestivum L.). Water, Air, and Soil Pollution, 85, 1449-1454.

Nussbaum S, Geissmann M, Saurer M, Siegwolf R, Fuhrer J (2000) Ozone and low concentrations of nitric oxide have similar effects on carbon isotope discrimination and gas exchange in leaves of wheat (Triticum aestivum L.). Journal of Plant Physiology, 156, 741-745.

Ojanpera K, Patsikka E, Ylaranta T (1998) Effects of low ozone exposure of spring wheat on net $\mathrm{CO}_{2}$ uptake, Rubisco, leaf senescence and grain filling. New Phytologist, 138, 451-460.

Pleijel H, Eriksen AB, Danielsson H, Bondesson N, Selldén G (2006) Differential ozone sensitivity in an old and a modern Swedish wheat cultivar - grain yield and quality, leaf chlorophyll and stomatal conductance. Environmental and Experimental Botany, 56, 63-71.

Pleijel H, Skarby L, Wallin G, Selldén G (1991) Yield and grain quality of spring wheat (Triticum aestivum L., cv. Drabant) exposed to different concentrations of ozone in open-top chambers. Environmental Pollution, 69, 151-168.

Rudorff BFT, Mulchi CL, Daughtry CST, Lee EH (1996) Growth, radiation use efficiency, and canopy reflectance of wheat and corn grown under elevated ozone and carbon dioxide atmospheres. Remote Sensing of Environment, 55, 163-173.

Rudorff BFT, Mulchi CL, Fenny P, Lee EH, Rowland R (1996) Wheat grain quality under enhanced tropospheric $\mathrm{CO}_{2}$ and $\mathrm{O}_{3}$ concentrations. Journal of Environmental Quality, 25, 1384-1388.

Rudorff BFT, Mulchi CL, Lee EH, Rowland R, Pausch R (1996) Effects of enhanced $\mathrm{O}_{3}$ and $\mathrm{CO}_{2}$ enrichment on plant characteristics in wheat and corn. Environmental Pollution, 94, 53-60.

Runeckles VC, Palmer K (1987) Pretreatment with nitrogen dioxide modifies plant response to ozone. Atmospheric Environment, 21, 717-719.

Sandelius AS, Naslund K, Carlsson AS, Pleijel H, Selldén G (1995) Exposure of spring wheat (Triticum aestivum) to ozone in open-top chambers. Effects on acyl lipid composition and chlorophyll content of flag leaves. New Phytologist, 131, 231-239.

Saurer M, Fuhrer J, Siegenthaler U (1991) Influence of ozone on the stable carbon isotope composition, ${ }^{13} \mathrm{C}$, of leaves and grain of spring wheat (Triticum aestivum L.). Plant Physiology, 97, 313-316.

Sild E, Pleijel H, Selldén G (2002) Elevated ozone $\left(\mathrm{O}_{3}\right)$ alters carbohydrate metabolism during grain filling in wheat (Triticum aestivum L.). Agriculture, Ecosystems and Environment, 92, 71-81.

Soja G, Soja AM (1995) Ozone effects on dry matter partitioning and chlorophyll fluorescence during plant development of wheat. Water, Air, and Soil Pollution, 85, 1461-1466.

Tiedemann AV, Firsching KH (2000) Interactive effects of elevated ozone and carbon dioxide on growth and yield of leaf rust-infected versus non-infected wheat. Environmental Pollution, 108, 357-363.

Velissariou D, Barnes JD, Davison AW (1992) Has inadvertent selection by plant breeders affected the $\mathrm{O}_{3}$ sensitivity of modern Greek cultivars of spring wheat? Agriculture, Ecosystems and Environment, 38, 79-89. 